\title{
Retraction: End-of-life discontinuation of destination therapy with cardiac and ventilatory support medical devices: physician-assisted death or allowing the patient to die?
}

\author{
Mohamed Y Rady ${ }^{1 *}$, Joseph $L$ Verheijde ${ }^{2}$
}

The authors have voluntarily retracted this article [1] and it is no longer available for online public display because portions of the article are similar to a previous publication [2]. While there was no intention to use pre-existing work without appropriate attribution, the authors nonetheless extend their apologies to Dr. Miller and all others concerned.

\begin{abstract}
Author details
'Department of Critical Care Medicine, Mayo Clinic Hospital, Mayo Clinic, 5777 East Mayo Boulevard, Phoenix, Arizona, USA, 85054; Center for Biology and Society, School of Life Sciences, Arizona State University, 300 East University Drive, Tempe, Arizona, 85287, USA. ${ }^{2}$ Department of Physical Medicine and Rehabilitation, Mayo Clinic Hospital, Mayo Clinic, 5777 East Mayo Boulevard, Phoenix, Arizona, USA, 85054; Department of Biomedical Ethics, College of Medicine, Mayo Clinic; and Center for Biology and Society, School of Life Sciences, Arizona State University, 300 East University Drive, Tempe, Arizona, 85287, USA
\end{abstract}

Received: 16 December 2010 Accepted: 21 December 2010 Published: 21 December 2010

\section{References}

1. Rady MY, Verheijde JL: End-of-life discontinuation of destination therapy with cardiac and ventilatory support medical devices: physician-assisted death or allowing the patient to die? BMC Medical Ethics 2010, 11:15.

2. Miller FG, Truog RD, Brock DW: Moral Fictions and Medical Ethics. Bioethics 2010, 24(9):453-460, Published online: 7 July 2009.

\footnotetext{
* Correspondence: rady.mohamed@mayo.edu

'Department of Critical Care Medicine, Mayo Clinic Hospital, Mayo Clinic, 5777 East Mayo Boulevard, Phoenix, Arizona, USA, 85054; Center for Biology and Society, School of Life Sciences, Arizona State University, 300 East University Drive, Tempe, Arizona, 85287, USA

Full list of author information is available at the end of the article
}

\section{Pre-publication history}

The pre-publication history for this paper can be accessed here: http://www.biomedcentral.com/1472-6939/11/20/prepub

\section{doi:10.1186/1472-6939-11-20}

Cite this article as: Rady and Verheijde: Retraction: End-of-life discontinuation of destination therapy with cardiac and ventilatory support medical devices: physician-assisted death or allowing the patient to die?. BMC Medical Ethics 2010 11:20.
Submit your next manuscript to BioMed Central and take full advantage of:

- Convenient online submission

- Thorough peer review

- No space constraints or color figure charges

- Immediate publication on acceptance

- Inclusion in PubMed, CAS, Scopus and Google Scholar

- Research which is freely available for redistribution

\section{() Biomed Central}

C Biomed Central 